\title{
Alternative Causality Theory: An Effort to Block Instrumental Communication Actions by Investigator in Determining a Suspect
}

\author{
Andi Muliyono ${ }^{1}$ and Rocky Marbun ${ }^{2}$ \\ \{andimulyono528@gmail.com ${ }^{1}$, rocky_marbun@univpancasila.ac.id² \\ Manokwari College of Law, Karya ABRI Street, West Papua ${ }^{1}$, Faculty of Law, Pancasila University, \\ Srengseng Sawah Street, Jakarta²
}

\begin{abstract}
The externalization of an idea of respect for human rights in the preadjudication process - especially the investigation and investigation stage, has gained juridical legitimacy through the Constitutional Court Decision Number 021 / PUU-XII / 2014 by expanding the pretrial object in Article 77 of the Criminal Procedure Code, namely by adding the Determination of Suspects, Confiscations, and Searches. However, with regard to the Determination of a Suspect, Investigators always argue only on formal aspects through instrumental communication. Thus, the decision to determine a suspect is no longer a process of interpretation that is linked between the causes and consequences of the elements of offense and the process of finding and gathering evidence. This study aims to apply alternative causality theory as a basis for thinking in interpreting evidence in the pre-adjudication domain. This study uses a legal research method that uses a conceptual approach, statute approach and a social science approach from the Critical Paradigm with a critical discourse analysis approach. The results of this study indicate that there is a decision to determine a suspect which is only based on a choice of causes that lead to assumptive consequences.
\end{abstract}

Keywords: Instrumental, Investigator, Searches.

\section{Introduction}

The idea of enacting Law Number 8 of 1981 concerning Criminal Procedure Law (Law No. 8/1981) - known as the Criminal Procedure Code, was based on past experience - when still using HIR as a criminal procedural law, and the desire to eliminate colonialism [1] in laws and regulations and respect for human rights [2]. This is as contained in the Consideration of the letter a of the Criminal Procedure Code which emphasizes "that the Republic of Indonesia is a state based on Pancasila and the 1945 Constitution which upholds human rights and guarantees that all citizens have equal position in law and government and are obliged to uphold law and government without exception."

Based on the foregoing, the Criminal Procedure Code has the aim of fostering attitudes towards law enforcers based on their function and authority.[3] This implies that there is an obligation for law enforcers to have a pattern of behavior as stipulated in the legal norms contained in the KUHAP. This means that any legal action by law enforcement officials is not justified when it deviates from what has been determined by the Criminal Procedure Code. 
However, not every legal action taken by law enforcement officials in the Criminal Procedure Code is the object of a pretrial petition as a legal instrument for every person suspected of committing a criminal act to fight for their human rights. Article 77 of the Criminal Procedure Code - which later expanded its legal norms through the Decision of the Constitutional Court Number 021 / PUU-XII / 2014 dated 28 April 2015, contains limits on legal actions that can be filed in pretrial, namely determination of suspects, arrest, detention, search, confiscation, compensation and rehabilitation. Thus, the object of the pretrial request other than the seven things that we have mentioned, will result in rejection of the pretrial application by the court.

Determination of a suspect - in relation to this research, is one of the objects of extension of Article 77 of the Criminal Procedure Code which is often requested as the object of pretrial petition through the District Court. The authority of the investigator in determining the person is based on the concept of investigation in the Criminal Procedure Code. Where in Article 1 point 2 of the Criminal Procedure Code which affirms "Investigation is a series of actions by the investigator in terms and according to the manner stipulated in this law to seek and collect evidence which with that evidence sheds light on the criminal act that has occurred and in order to find the suspect."

The Constitutional Court interprets this provision by explaining the phrase "and in order to find the suspect" it must be interpreted conditionally, according to the Court, that the investigator in a series of investigative actions carries out a process of gathering evidence with the evidence then the investigator finds the suspect in a criminal act so that the investigator does not immediately find suspects before collecting evidence [4]. This explanation implies that there is a process of thinking and a process of interpreting between an act that is suspected of being a criminal event - as a result of an investigation, the elements of the article that is allegedly violated and the evidence that has been collected.

However, even though the Constitutional Court has stipulated that there are requirements in determining a person as a suspect, namely that the investigator must have two pieces of evidence based on Article 184 of the Criminal Procedure Code, which is determined first in the case title process. Ironically, the Criminal Procedure Code adopts an interpretation model that is strictissima interpretatie or strictissima interpretaio, or as a strictissimae interpretatio. Where according to Andi Sofyan, if we read the entire formulation of the articles in the Criminal Procedure Code, none of the formulations of the articles provide the possibility or allow people to give other meanings or interpretations to the words that have been used by the legislators in the formulation of the articles. So all the words contained in the formulation of the articles of the Criminal Procedure Code are always interpreted according to the meaning intended by the legislators [5].

Thus, the determination of a person as a suspect is truly based on the minimum requirements for evidence, namely two pieces of evidence, without considering the relevance or causality between the evidence and the elements of the article that the investigator charges. This can be seen in the case in the Gorontalo District Court Decision Number 4 / Pid.Prap / 2017 / PN.Gto, where a person is declared a suspect in a criminal act of fraud based on a Police Report and Transfer Slip. According to Arif Ferdian Junaedi and Setiyono, this is a 
form of inconsistency between the evidence and the alleged article, or in other words, the alleged articles have no relevance to the evidence possessed by the investigator [6].

Another phenomenon, which is related to the relevance of evidence and suspected elements, is in the Police Report Number: 1431 / IV / 2014 / PMJ / Dit Reskrimum dated 23 April 2014 in the case of alleged criminal defamation and / or slander as referred to in Article 310 paragraph (1) of the Criminal Code and / or Article 311 paragraph (1) of the Criminal Code. Where, in this case, the investigator has determined a person as a suspect under the allegation of Article 310 paragraph (1) of the Criminal Code, which is about the Crime of Defamation through acts of speech / speech, without any evidence that represents the suspect's act of defamation.

On the other hand, one of the means of collecting evidence is through forced confiscation, according to Mudzakkir, the provisions of Article 82 paragraph (3) letter d of the Criminal Procedure Code implicitly interpreted those pretrial institutions have the authority to test the use of investigator's power to carry out confiscations, namely testing. whether the confiscated goods are relevant for the purpose of proving a criminal case being investigated or not. If, the result of the examination turns out that the confiscation of the object is irrelevant to the evidence of the criminal case being investigated by the investigator, the pretrial judge declares the confiscation of the object illegal, then the data on the dictum of the court decision shall be declared returned to the suspect or from whom the object was confiscated [7]. The relevant nature was also revealed by Eddy OS Hiariej[8], where evidence must be relevant to the dispute or case being processed. That is, the evidence relates to facts that point to the truth of an event.

Based on the foregoing, it is important to apply a model of causality teaching as a thought process and an interpreting process in the investigation process to determine the right choice of the decision to make a forced attempt in the form of the determination of the suspect

\section{Research Method}

In this study, we used a normative juridical research method based on a conceptual approach, a legal approach, and a social science approach derived from the critical paradigm, namely the critical discourse analysis approach. The use of the critical paradigm, especially the critical discourse analysis approach, is based on the features of the method used by allowing various models of approaches to obtain a complete description of legal phenomena that occur in the investigation process.

\section{Analysis and Discussion}

\subsection{Critical Discourse Analysis}

Discourse is a term often used by society today. There are a number of definitions of the term discourse. In the field of sociology, discourse refers primarily to the social context of language usage. In the field of linguistics, discourse is a larger unit of language than sentences. There are three central things in relation to the notion of discourse, namely text, context, and discourse. Eriyanto explains the three meanings as follows: Text is all forms of language, not only words printed on sheets of paper, but also all kinds of communication expressions, speech, music pictures, sound effects, images, and so on. Context includes all 
situations and things that are outside the text and affect the use of language, such as participants in language, situations in which the text is produced. Discourse here is interpreted as text and context together [9].

In the Collins Concise English Dictionary (1988) it is stated that discourse is 1) verbal communication, speech, conversation; 2) a formal treatment of the subject in speech or writing; 3) a unit of text used by linguists to analyze more units than sentences. Whereas J.S.Badudu stated that discourse was 1) a series of related sentences, which connected one proposition to another, forming a unity, so that a harmonious meaning was formed between the sentences; 2) the most complete and highest or greatest language unity above sentences or clauses with continuous high coherence and cohesion, capable of having a real beginning and ending, conveyed orally and in writing $[10]$.

One of the initiators of Critical Discourse Analysis, Fairclough, explains the concept of discourse which seeks to combine several traditions, namely linguistics, interpretive traditions, and sociology. Fairclough offers a discourse model that contains three dimensions of discourse analysis, namely the dimensions of text, discourse practice, and sociocultural practice. (a) The dimensions of the text (microstructural) are analyzed linguistically, namely by looking at vocabulary, semantics, and syntax; (b) Discourse practice (mesostructured) is a dimension related to the process of producing and consuming text; and (c) Sociocultural practice (macrostructural) is a dimension related to contexts outside the text. The three dimensions are then analyzed using three different stages of analysis, namely (1) the description is used to analyze the text, including cohesion and coherence, grammar, and diction, (2) interpretation is used to analyze the interpretation of the text, including production, distribution, and consumption text, and (3) explanations are used to analyze sociocultural practices that include the situational, institutional, and social levels [11].

The use of a critical paradigm for discourse analysis causes the Critical Discourse Analysis approach to not only be understood as a language study that examines language not only from the linguistic aspect, but also relates it to the context. Context here means that language is used for certain purposes and practices, including the practice of power. Critical discourse analysis is considered more suitable for analyzing public discourse.[12]

The use of critical discourse analysis (Critical Discourse Analysis) - as a research approach, culminates in an analysis of social relations between the parties involved in the discourse. Critical Discourse Analysis reveals the sources of domination and inequality observed in society and is in the form of criticism of linguistics and sociological and cultural developments in social domains with the aim of explaining the linguistic dimensions of social and cultural phenomena and the processes of change in recent modernity [13]. Therefore, Critical Discourse Analysis has several principles in its use, namely [10]:

a. Action. Discourse is understood as an action. Or discourse is also understood as a form of interaction. So, discourse is something that aims, for example whether to influence, argue, persuade, argue, and so on. Discourse is also something that is expressed consciously and in control.

b. Context. In discourse analysis, it also examines the context of communication such as who communicates with whom and why; in what types of audiences and situations; through what medium; how different types of communication develop; and relationships for each party. In relation to context in discourse, Fillmore revealed how important the role of context is to determine the meaning of an utterance, if the context changes, the meaning will change. As for differentiating the context in using language into four types: (1) physical context which includes the place where the use of language occurs in a communication, the objects presented in the communication event, and the actions or 
behavior of the roles in that communication; (2) the epistemic context or background of knowledge which is known to both the speaker and the listener; (3) linguistic context which consists of sentences or utterances that precede a sentence or certain utterances in a communication event; and (4) social context, namely social relations and setting settings that complement the relationship between the speaker and the listener.

c. Historical. To be able to understand a text discourse, it can be done by providing the historical context in which the text was created. Therefore, when analyzing, it is necessary to understand why the discourse is developing or developed like that, why the language is used like that, and so on.

d. Power. All discourse that appears in the form of text, conversation, or whatever is seen as a form of power struggle. The concept of power is one of the key relationships between discourse and society. The relationship between power and discourse can be seen from what is called control. Control in a discourse can be in the form of control over context and control over the structure of discourse. Control over context, for example, can be seen from who can or should speak while the other positions are as listeners or who agree. Meanwhile, control over the structure of discourse can be seen from someone who has more power to determine which parts need to be presented and which parts should not be presented and how they should be presented.

e. Ideology. Discourse is used as a tool by the dominant group to persuade and communicate the power they have in order to make it appear valid and correct in the eyes of the public. A text, conversation and others are forms of certain ideological practices. According to ideological theories it is said that ideology is built by dominant groups with the aim of reproducing and legitimizing their domination. The main strategy is to build public awareness that domination can be taken for granted.

Several contexts are important because they influence discourse production. In general, this context is divided into two, namely first, gender, age, education, social class, ethnicity, religion, in many ways relevant in describing discourse; and second, certain social settings, such as place, time, the position of the speaker and listener or the physical environment are useful contexts for understanding a discourse. Settings, such as private or public places, in a formal or informal setting, or in certain spaces will also provide a certain discourse. Speaking in a courtroom is different from speaking in the marketplace, or speaking at home is different from speaking in a classroom, because the social situation and the rules that surround it are different, causing communication participants to adapt to the existing context [14].

Thus, one of the very important characteristics of critical discourse analysis is the involvement of context in seeing the use of language. Critical discourse analysis considers the context of discourse such as settings, situations, events, and conditions. Discourse in this case is produced, understood, and analyzed in a particular context. They further argue that discourse analysis also examines the context of communication: who communicates with whom and why; in what types of audiences and situations; through what medium; how different types of communication develop; and relationships for each party [15].

\subsection{Causality Teachings Alternative}

In constructing the Teaching of Alternative Causality, Ahmad Sofian [16] in his research explained the need to incorporate the doctrine of the novus actus interveniens into the teachings of causality so that it can be applied in Indonesia. The doctrine of the novus actus interveniens itself is a doctrine that grows and develops in the realm of the common law system. Novus actus interveniens or nova causa interveniens is a Latin term which is defined as the intervention of an independent third party. 
In the Black Law Dictionary, novus actus interveniens (nova causa interveneniens) is translated as intervening cause which is defined as "an event that comes between the initial event in a sequence and the end result, altering the natural course of events that might have connected a wrongful act to an injury".[16] This Novus actus interveniens later developed into a doctrine in the teaching of causality which was popularized by H.L.A. Hart and A.M. Honore in his book entitled "Causation in Law" which was first published in 1959. Both Hart and Honore are professors in law from Oxford University.

According to Ahmad Sofian, Novus actus in the common law family can have the same meaning as "new actions" or "new causes", "superseding", "extraneous", "intervening forces", intervening act, intervening agency, independent intervening cause which is described as the commencement of an act or action that can break a series of actions that have a causal relationship, so that this actus novus makes a causal relationship stops or soon stops moving or runs out of energy to continue the chain's journey. If only this chain is not broken then the chain will have the potential to "continue", "contribute", "walk" which will have certain consequences. An intervention exists between or in the middle of an event. If an intervention is strong enough, it can reduce the accountability of the perpetrator, and the party that intervenes can replace responsibility, but it should be noted that the intervening party is really an independent party, not a party who was forced or participated in so that it can replace this accountability.

Novus actus interveniens is defined by the two scientists as a "superseding cause" or "intervening causes" that can break the causality chain so as to eliminate accountability or reduce the level of responsibility of the main actors (principal offender). Thus, there is a "third party" who intervenes to break the chain of causality. If the third-party intervention is carried out by another actor, the intervention is carried out consciously, freely and without coercion [16].

There is a significant difference in determining the causal factors, in the doctrine that individualizing the method is to measure the most influential factors, so that the factors that do not affect are eliminated. Meanwhile, in the novus actus interveniens doctrine, on the contrary, it eliminates the factors considered to interfere. The factor that intervenes is considered as the factor that breaks the chain of the most influencing factors. However, according to Ahmad Sofian [16], this most influential factor can in some cases be equated with the novus actus intervention.

\subsection{Implementation of Alternative Causality Teachings in the Investigation Process Based on Critical Discourse Analysis}

Based on the descriptions above, in essence, Ahmad Sofian introduced the doctrine of novus actus interveniens into the teaching of causality which has a function, not only to determine the most influential factors originating from outside the perpetrator, but to determine other factors that may contribute from these factors are to eliminate and / or reduce the level of accountability, in the process of evidence in court proceedings.

However, in this study, we try to apply the alternative teaching of causality based on the novus actus intervention doctrine into an initial process of the entire criminal justice process, namely in relation to the evidentiary process in the investigation stage to determine a person as a suspect. Based on common sense logic in the Criminal Procedure Code, a process of evidence - normatively, is confirmed as a process that only exists in the trial process before a court session after going through the stages of reading the indictment and filing objections from the defendant or his attorney. 
However, if we pay attention to the provisions in Article 1 point 2 of the Criminal Procedure Code which emphasizes "Investigation is a series of actions by an investigator in matters and according to the manner stipulated in this law to seek and collect evidence which with that evidence makes clear about the criminal act that occurred and in order to find the suspect. " In the phrase ".... makes light....", is strung after the phrase "....to find and collect evidence with that evidence....", thus, the phrase "make light...." Said - in essence, is a legal act committed by an investigator as a public official which gives rise to legal consequences for a person suspected of committing a criminal act. The phrase "make light" is a representation of the activities of Law Science, namely the interpretation of law. The direction of the legal interpretation is directed at fostering confidence in investigators in order to prove that a person is worthy of being declared a suspect.

The process of "... to find and collect evidence with that evidence" as a form of a series of investigative actions, then obtained restrictions through the Constitutional Court Decision Number 021 / PUU-XII / 2014 which is based on two things, namely based on two evidence refers to Article 184 paragraph (1) of the Criminal Procedure Code and is preceded by a process for examining potential suspects. Then, referring to the Decision of the Constitutional Court Number 65 / PUU-VIII / 2010 which confirms that it is a normative right for someone to present mitigating evidence which is considered by the suspect to be relevant evidence. Thus, it is an obligation for investigators to accommodate the evidence

As another example, in the Police Report Number: LP / 5464 / IX / 2019 / PMJ / Ditrekrimum dated September 1, 2019 concerning cases of alleged falsification and / or ordering to put false information into authentic deeds and / or embezzlement of rights over immovable property and / or entering a yard without permission and / or participating in a criminal act, as referred to in Article 263 KUHP and or Article 266 KUHP and / or Article 385 KUHP and / or Article 167 KUHP and / or Article 55 KUHP, which occurred on June 16, 2017 at the Land Agency Office National (BPN) Depok City.

As it was later discovered, that a person being a suspect by the Investigator was only leaning on evidence presented by the Reporting Party. Ironically, the suspect has tried to present evidence in the form of a National Land Agency Letter, West Java Province Regional Office No. MP.01.01 / 1152-32.600 / VIII / 2020 dated 03 August 2020 to eliminate evidence from the Reporting Party, but this was not considered by the Investigator. In fact, without any coordination with the Depok City National Land Agency (BPN), investigators have arbitrarily designated the suspect as "land mafia".

Based on the illustrations of the three cases that we have conveyed in this study, then when referring to the Critical Discourse Analysis, the Investigator forms a discourse (action) that is non-impartial and based only on reports from the Reporting Party. In order to perpetuate this non-impartial discourse, it appears that the Investigator has formed a different model of communication towards the parties. Such non-impartial action - which overrides the legal interests of the suspect, is constructed based on conventions that grow and develop within the scope of investigation when a person is named a suspect. On the other hand, based on Critical Discourse Analysis, in the aforementioned case, it appears that the use of power to safeguard the interpretation of the law that has been established by law. Thus, the Investigator's control over the course of the evidentiary process in the realm of investigation is absolute.

Although, there is a Constitutional Court Decision Number 021 / PUU-XII / 2014, the fulfillment of the evidence is only based on the fulfillment of formal requirements, as confirmed in the Supreme Court Circular Letter Number 4 of 2016. So, based on this power, the problem of the relevance of evidence is not mandatory for Investigators. Thus, 
investigators will freely achieve their interests (ideology) based on an "agreement" with the reporting party. In the Police Report Number: LP / 5464 / IX / 2019 / PMJ / Ditrekrimum dated September 1, 2019, then the Letter of the National Land Agency, West Java Province Regional Office No. MP.01.01 / 1152-32.600 / VIII / 2020 dated 03 August 2020 is a novus actus interveniens, which must be presented based on Article 65 in conjunction with Article 116 paragraph (3) and paragraph (4) KUHAP.

This obligation, if implemented, should be able to shift the investigator's "belief" in interpreting the law so that it does not make the investigation process continue. Likewise, in the Police Report Number: 1431 / IV / 2014 / PMJ / Dit Reskrimum, April 23, 2014, with the emergence of legal facts in which a person as the perpetrator of speech / speech has died, then the other suspect should be aborted - It is really known, does not commit acts of speech / utterance classified in Article 310 paragraph (1) of the Criminal Code. Therefore, these concrete facts should be the novus actus intervention in the case.

\section{Conclusion}

The existence of the doctrine of novus actus interveniens in the teaching of causality is very important for policy makers in the realm of investigation to consider the integrity of the evidence collected and found in a series of investigations, not only based on the absolutism of the legal interpretation of the investigator from the reporting party. However, it should also be obliged to collect and find for a balanced legal interpretation of the suspect, as mandated by Article 65 in conjunction with Article 116 paragraph (3) and paragraph (4) in conjunction with the Constitutional Court Decision Number 021 / PUU-XII / 2014 in conjunction with the Court Decision. Constitution Number 65 / PUU-VIII / 2010.

\section{Acknowledgements}

Researchers are very grateful to those who have helped to materialize this research. The researchers' gratitude goes to the Dean of the Faculty of Law, Trunojoyo University, Madura, and the Dean of the Faculty of Law, Pancasila University.

\section{References}

[1] S. Bakhri, "Melepas Belenggu Hukum Pidana Kolonial," 2018.

[2] S. Karim, "Koridor Hak Asasi Manusia dalam Hukum Acara Pidana Indonesia: Sebuah Instropeksi atas Nilai-Nilai Politik Kenegaraan dalam Pembangunan Hukum di Indonesia,” J. Demokrasi., vol. II, no. 1, 2003.

[3] R. Indonesia, Hukum Acara Pidana. 1981

[4] M. Konstitusi, Putusan. 2014.

[5] A. Sofyan, Hukum Acara pidana: Suatu Pengantar. Yogyakarta: Rangkang Education, 2013.

[6] A. F. Junaedi and Setiyono, "Analisis Yuridis Atas Penetapan Tersangka Aprianto Oleh Penyidik Kepolisian Daerah Gorontalo (Studi Putusan Praperadilan Pengadilan Negeri Gorontalo Nomor 4/Pid.Prap/2017/PN.GTO.” $\quad$ https://trijurnal.lemlit.trisakti.ac.id/refor/article/viewFile/7147/5400 (accessed Feb. 15, 2021).

[7] Mudzakkir, "Pembatasan dan Perluasan Hakikat Praperadilan Menurut Hukum Acara Pidana: Telaah Putusan Praperadilan Komjen Pol BG," Jakarta, 2015.

[8] E. O. S. Hiariej, Teori \& Hukum Pembuktian. Jakarta: Erlangga, 2012.

[9] Supriyadi, "Analisis Wacana Kritis: Konsep dan Fungsinya Bagi Masyarakat," 
[10] AKSARA, vol. 16, no. 2, 2015.

[11] S. Ismail, “Analisis Wacana Kritis: Alternatif Menganalisis Wacana,” J. BAHAS, vol. 34, no. 69, 2008, doi: https://doi.org/10.24114/bhs.v0i69TH XXXV.2430.

[12] R. C. Cenderamata and N. Darmayanti, "Analisis Wacana Kritis Fairclough Pada Pemberitaan Selebriti Di Media Daring,” J. Literasi, vol. 3, no. April, pp. 1-8, 2019, [Online]. Available: https://www.researchgate.net/publication/331830467_ANALISIS_WACANA_KRITIS_FAI

RCLOUGH_PADA_PEMBERITAAN_SELEBRITI_DI_MEDIA_DARING_FAIRCLOUG H'S CRITICAL DISCOURSE_ANALYSIS_OF_CELEBRITY_NEWS_ON_ONLINE_M EDIA.

[13] Y. A. Darma, Analisis Wacana Kritis. Bandung: Yrama Widya, 2009.

[14] R. A. Fitriana, E. Gani, and S. Ramadhan, "Analisis Wacana Kritis Berita Online Kasus Penipuan Travel Umrah (Model Teun a. Van Dijk)," BASINDO J. Kaji. bahasa, sastra Indones. dan pembelajarannya, vol. 3, no. 1, pp. 44-54, 2019, doi: 10.17977/um007v3i12019p044.

[15] R. Marbun, W. Oedoyo, and D. M. Sinaga, "Logika Monolog Dalam Trikotomi Relasi Pada Proses Pra-Adjudikasi Terhadap Pasal 72 KUHAP jo Pasal 143 ayat (4) KUHAP," Ja, 2021.

[16] U. Fauzan, "Analisis Wacana Kritis Dari Model Fairclough Hingga Mills," J. PENDIDIK, vol. 6, no. $1,2014$.

[17] A. Sofian, "Novus Actus Interveniens Dalam Konteks Hukum Pidana di Indonesia," in Konferensi Asosiasi Filsafat Hukum Indonesia Ke-5, 2015, no. November 2015. 